\title{
R. Revista

\section{Reforestation of a Degraded Area with Eucalyptus and Sesbania: Microbial Activity and Chemical Soil Properties}

\author{
Vanderlan de Oliveira Paulucio(1), Cristiane Figueira da Silva ${ }^{(2)}$, \\ Marco Antônio Martins ${ }^{(3)}$, Marcos Gervasio Pereira ${ }^{(4) *}$, Jolimar Antonio Schiavo ${ }^{(5)}$ \\ and Luciana Aparecida Rodrigues ${ }^{(3)}$ \\ (1) Universidade Federal do Espírito Santo, Centro Agropecuário, Centro de Ciências Agrárias, \\ Laboratório de Fitopatologia, Alegre, Espírito Santo, Brasil. \\ (2) Universidade Federal Rural do Rio de Janeiro, Departamento de Engenharia Florestal, Programa de \\ Pós-graduação em Ciências Ambientais e Florestais, Seropédica, Rio de Janeiro, Brasil. \\ (3) Universidade Estadual do Norte Fluminense Darcy Ribeiro, Centro de Ciências e Tecnologias \\ Agropecuárias, Campos dos Goytacazes, Rio de Janeiro, Brasil. \\ (4) Universidade Federal Rural do Rio de Janeiro, Departamento de Solos, Seropédica, Rio de Janeiro, Brasil. \\ (5) Universidade Estadual de Mato Grosso do Sul, Departamento de Solos, Aquidauana, Mato Grosso do Sul, Brasil.
}

* Corresponding author: E-mail: mgervasiopereira01@ gmail.com

Received: May 2, 2016

Approved: January 30, 2017

How to cite: Paulucio Vo, Silva CF, Martins MA, Pereira MG, Schiavo JA, Rodrigues LA. Reforestation of a degraded area with Eucalyptus and Sesbania: microbial activity and chemical soil properties. Rev Bras Cienc Solo. 2017:41:e0160239.

https://doi.org/10.1590/18069657rbcs20160239

Copyright: This is an open-access article distributed under the terms of the Creative Commons Attribution License, which permits unrestricted use, distribution, and reproduction in any medium, provided that the original author and source are credited.
ABSTRACT: Mining activities generally affect soil quality, degrading it and creating the need for consistent environmental recovery efforts. This study evaluates the influence of monospecific and mixed stands of Sesbania virgata (S) and Eucalyptus camaldulensis (E) on the chemical properties and microbial activity of the soil in a degraded area by clay extraction in the northern part of the state of Rio de Janeiro, Brazil. Four treatments (100S:100\% Sesbania, 100E: $00 \%$ Eucalyptus, 50S:50E: $50 \%$ Sesbania + $50 \%$ Eucalyptus, and DASV: a degraded area with spontaneous vegetation) were established according to a randomized complete block design with three replicates. Samples were collected in the 0.00-0.10 m layer in the rainy season (March) and the dry season (September). The properties evaluated were $\mathrm{pH}$ in water; contents of $\mathrm{P}, \mathrm{K}^{+}, \mathrm{Ca}^{2+}, \mathrm{Mg}^{2+}, \mathrm{Al}^{3+}, \mathrm{H}+\mathrm{Al}$, $\mathrm{N}$, and $\mathrm{C} ; \mathrm{C} / \mathrm{N}$ ratio; total microbial activity (soil respiration $-\mathrm{CO}_{2}$ emission); and total enzymatic activity (fluorescein diacetate hydrolysis). The reforestation of degraded areas by clay mining with the species $S$. virgata and $E$. camaldulensis either in monospecific or mixed stands increased the nutrient contents, $C$ levels, and total microbial activity in the soil. It was possible to separate the planting systems (100S, 100E, 50S:50E) and the DASV using principal component analysis. In both seasons, soil C contents, chemical properties, and biological variables improved in the planted areas, in contrast with the DASV. The revegetation of degraded areas by mining improved the chemical and biological properties of the soil, leading to higher soil quality in revegetated areas compared to degraded areas with natural vegetation.

Keywords: soil respiration, fluorescein diacetate hydrolysis, clay extraction. 


\section{INTRODUCTION}

Clay mining for the production of ceramic tiles and bricks has great socioeconomic importance (more than 120 companies generating approximately 52 million dollars annually and directly creating 4,500 jobs) for the municipality of Campos de Goytacazes (RJ), Brazil. However, such activity degrades an area of approximately $3,500 \mathrm{~m}^{2}$ per day at depths of 1 to $4 \mathrm{~m}$ (Ramos et al., 2006; Rodrigues et al., 2006; Valicheski et al., 2009). Some of these areas are being revegetated with single species and/or mixed commercial forest species (Eucalyptus spp.) and fast-growing nitrogen-fixing legumes (Mendonça et al., 2008; Santiago et al., 2009; Schiavo et al., 2010). The intention in planting such crops is to improve soil quality and produce wood (Eucalyptus) to be used as fuel in the manufacturing process of ceramics (Schiavo, 2005).

Planting legumes in combination with Eucalyptus has been suggested due to the unsatisfactory development of Eucalyptus stands in these revegetation areas compared to commercial plantations (Schiavo et al., 2010). These species can contribute to the nutrition and biomass production of Eucalyptus by increasing $\mathrm{N}$ availability in the soil and accelerating the nutrient cycling process (Rodrigues et al., 2003; Forrester et al., 2004; Voigtlaender et al., 2012; Silva et al., 2013; Koutika et al., 2014; Paula et al., 2015). In addition, legumes can favor the formation of humic substances in the soil, which increases the $C$ stock and improves soil chemical properties (Vezzani et al., 2001; Garay et al., 2003; Mendonça et al., 2008; Schiavo et al., 2009; Forrester et al., 2013; Koutika et al., 2014).

Sesbania virgata is an important legume for recovery of clay mining sites because it occurs frequently in natural revegetation of abandoned pits, its seeds are highly available, and it is able to form symbioses with $\mathrm{N}_{2}$-fixing bacteria (Samôr, 1999; Coutinho et al., 2006; Schiavo et al., 2010). In addition, some authors (Santos et al., 2013; Silva et al., 2013) have observed positive effects of this species on the chemical and biological properties of the soil.

The continuous build-up of litterfall on the ground is one of the main issues in forest management. This build-up is a consequence of long rotation periods, and, together with root death, increases the amount and permanence of soil organic matter (Gatto et al., 2010; Viera et al., 2014). Organic matter has been reported as one of the main soil properties affecting the size and activity of the microbial population (Klose and Tabatabai, 2000; Carneiro et al., 2009). The significant role played by microorganisms in the sustainability and productivity of terrestrial systems has been widely investigated (Silva et al., 2004; Schulz et al., 2013). Microorganisms are directly or indirectly responsible for a variety of microbiological and biochemical processes, especially in nutrient cycling and soil fertility (Carvalho et al., 2008; Schulz et al., 2013).

Microbial respiration and the hydrolysis of fluorescein diacetate (FDA) are some of the parameters most commonly used to evaluate microbial activity in soils; they define the total enzymatic activity in a soil where microorganisms are the main source of enzymes (Pereira et al., 2004; Green et al., 2006; Batista et al., 2008; Carvalho et al., 2008; Carneiro et al., 2009; Evangelista et al., 2012). Research has shown that these factors are significantly influenced by soil use and management methods (Pell et al., 1998; Stenström et al., 1998; Arshad and Martin, 2002; Schloter et al., 2003; Gil-Sotres et al., 2005; Batista et al., 2008).

Respiration rates are a key source of information regarding $\mathrm{CO}_{2}$ emissions. It is known that respiration may be affected by any imbalance in soil biological components, such as organic matter levels and soil biota, as a consequence of the management practices adopted in a given area (Carvalho et al., 2008). Because residue decomposition increases the levels of nutrients available to plants, high short-term respiration rates may be interpreted as a desirable characteristic (Carter, 1986; Roscoe et al., 2006; Batista et al., 2008). 
The hydrolysis of FDA measures the specific activity of proteases, lipases, esterases, and other enzymes that hydrolyze FDA (Guilbault and Kramer, 1964; Rotman and Papermaster, 1966; Taylor et al., 2002). These enzymes catalyze several reactions of central importance in the life cycle of microorganisms, the decomposition of organic residue during nutrient cycling, the formation of organic matter, and the establishment of a given soil structure (Burns, 1978). Therefore, recovery of the capacity to hydrolyze FDA may affect the energy cycle in the soil-plant system, and this capacity becomes a parameter of central importance in strategies for restoring areas under anthropic change (Carneiro et al., 2008).

For that reason, accurate assessment of soil microbiota is an important factor in the determination of the biological quality of soils because this assessment produces data relevant to the development of strategies for recovery of degraded areas (Li et al., 2014; Lal, 2015).

The hypothesis of this study is that monospecific and mixed planting of Eucalyptus camaldulensis (E) and S. virgata (S) contribute to improve the chemical and microbiological properties in areas where the soil is degraded by clay extraction. Thus, in this study, we evaluated the effects of monospecific and mixed stands of Eucalyptus camaldulensis and Sesbania virgata on the chemical properties of soils (namely nutrient and C levels) and on the microbial populations and total levels of soil enzyme activity as measured by the FDA assay in a degraded area by clay mining operations in the northern part of the state of Rio de Janeiro, Brazil.

\section{MATERIALS AND METHODS}

\section{Location and characterization of the experimental site}

This study was conducted in a clay pit owned by a ceramics company (Stilbe) located in the Poço Gordo district ( $21^{\circ} 50^{\prime} 28.5^{\prime \prime}$ S; 41 $1^{\circ} 14^{\prime} 31.4^{\prime \prime}$ W), municipality of Campos dos Goytacazes, RJ, Brazil. The climate in the region is classified as Aw (tropical hot and humid), according to the Köppen system. Winter is the dry season and summer is the rainy season. Mean annual rainfall is approximately $1,020 \mathrm{~mm}$. The climate data recorded during the study period are shown in figure 1.

The original soil of the pit area is an Inceptsol (Cambissolo Háplico Sódico gleico) to a depth of approximately $3 \mathrm{~m}$. In pit operations, the surface soil layer was initially removed

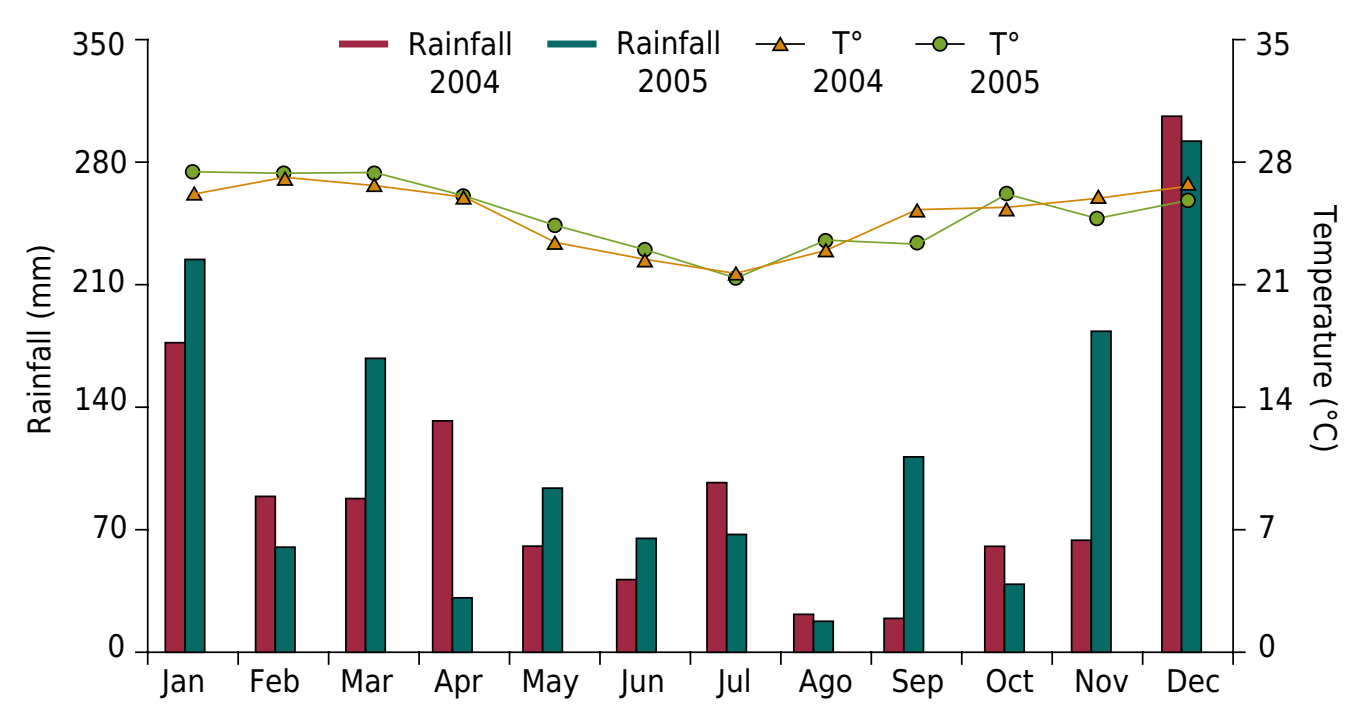

Figure 1. Monthly temperature and rainfall means for the years 2004 and 2005, recorded by the Leonel Miranda meteorological station in Campos dos Goytacazes, RJ, Brazil. 
and set aside. Clay extraction proceeded down to a depth of approximately $2.5 \mathrm{~m}$, at which point mining activities were interrupted; the surface layer was returned to the pit, mechanically leveled, and left to stand for two years. After this fallow period, the area was prepared by plowing and two harrowings. The pit areas were fertilized (except in the degraded area with spontaneous vegetation - DASV) with rock phosphate from Araxá (composition: $25.9 \%$ Ca, $11.6 \%$ total P, $5.9 \%$ available P) at an application rate of $100 \mathrm{mg} \mathrm{kg}^{-1}$.

The area within the pit shell was revegetated in August 2002 with Sesbania virgata (S) and Eucalyptus camaldulensis (E) in monospecific and mixed stands (Schiavo, 2005). After the seedlings were planted within the area defined by the pit shell, weed control, ant control, and irrigation were performed as needed (Schiavo, 2005).

Prior to tillage and planting in the area, chemical analysis of the $0.00-0.20 \mathrm{~m}$ layer of the substrate was conducted (Claessen, 1997), showing pH in $\mathrm{H}_{2} \mathrm{O} 5.70, \mathrm{P} 7.70 \mathrm{mg} \mathrm{dm}^{-3}$, $\mathrm{K} 81.20 \mathrm{mg} \mathrm{dm}^{-3}, \mathrm{Ca}^{2+} 3.65 \mathrm{cmol}_{\mathrm{c}} \mathrm{dm}^{-3}, \mathrm{Mg}^{2+} 2.87 \mathrm{cmol}_{\mathrm{c}} \mathrm{dm}^{-3}, \mathrm{Al}^{3+} 0.18 \mathrm{mg} \mathrm{dm}{ }^{-3}$, $\mathrm{H}+\mathrm{Al} 3.40 \mathrm{mg} \mathrm{dm}^{-3}$, and C $11.40 \mathrm{~g} \mathrm{~kg}^{-1}$ (Schiavo, 2005).

\section{Experimental design and treatments}

The experiment was carried out following a randomized complete block design with four treatments (three replicates), which were designated 100S (a monospecific Sesbania stand), 100E (a monospecific Eucalyptus stand), 50S:50E (a mixed Sesbania and Eucalyptus stand at identical proportions), and DASV (a degraded area with spontaneous vegetation in which Brachiaria mutica (Forsk.) Stapf. prevailed). Each quadrat included 16 plants spaced at $3 \times 2 \mathrm{~m}$. During seedling production, the plants were inoculated with arbuscular mycorrhizal fungi (Glomus macrocarpum, Glomus etunicatum, and Entrophospora colombiana) isolated from a clay pit that belonged to another ceramics company, Caco Manga Ltda., located in the Ururaí district, municipality of Campos dos Goytacazes, $\mathrm{RJ}$, Brazil. The isolates, which came from the inoculum bank maintained by the Laboratory of Soil Studies, Universidade Estadual do Norte Fluminense, were multiplied on Urochloa brizantha grown in a 1:2 (v:v) mixture of soil and sand. Inoculation was performed at the time of placing the seeds in the containers with an inoculum of $5 \mathrm{~mL}$ of a mixture of rhizospheric soil and fungal spores (approximately 120 spores of $G$. macrocarpum, 100 of $G$. etunicatum, and 80 of E. colombiana). In addition to the fungi, the $S$. virgata seeds were inoculated with $5 \times 10^{7}$ cells $\mathrm{mL}^{1}$ of the specific strain of Rhizobium (BR 5401) recommended as an inoculant for this species by Rede de Laboratórios para Recomendação, Padronização e Difusão de Tecnologia de Inoculantes Microbianos de Interesse Agrícola (RELARE), supplied by Embrapa Agrobiologia, Seropédica, RJ, Brazil.

\section{Soil sampling and analyses}

At 20 and 26 months after the species were planted in the pit (March 2004 and September 2004, in the rainy and the dry season, respectively), 12 simple soil samples were collected, in the interweaving of the plantations, with the aid of a Dutch auger at depths of $0.00-0.10 \mathrm{~m}$ in each quadrat and pooled for each quadrat. Total $\mathrm{C}$ and chemical properties $\left(\mathrm{pH}\right.$ in $\mathrm{H}_{2} \mathrm{O}, \mathrm{H}^{+}, \mathrm{Al}^{3+}, \mathrm{N}, \mathrm{P}, \mathrm{K}^{+}, \mathrm{Ca}^{2+}$, and $\mathrm{Mg}^{2+}$ ) were analyzed using air-dried soil obtained by drying the samples and passing them through a 2-mm mesh sieve. The $C$ and $\mathrm{N}$ contents were determined in a simultaneous CHNS/O elemental analyzer (PE 2400 series II, Perkin-Elmer, Norwalk, CT, USA), and the data obtained were used to calculate the $\mathrm{C}: \mathrm{N}$ ratio. The $\mathrm{P}$ contents were determined by colorimetry and the molybdate method, according to Malavolta et al. (1989). The K content (by flame emission spectrophotometry) and $\mathrm{Ca}$ and $\mathrm{Mg}$ contents (by mass absorption spectrophotometry) were determined as described in Claessen (1997).

The microbiological properties of freshly collected soil samples were identified using two methods: FDA hydrolysis (enzyme activity, as described by Chen et al., 1988) and 
respiration $\left(\mathrm{CO}_{2}\right.$ released, as described by Grisi, 1995). For fluorescein diacetate hydrolysis, $5 \mathrm{~g}$ samples of soil (two replicate analytical samples) were transferred to an Erlenmeyer flask (125 mL) along with $20 \mathrm{~mL}$ of sodium phosphate buffer and $0.2 \mathrm{~mL}$ of fluorescein diacetate stock $\left(2 \mu \mathrm{g} \mathrm{mL}^{-1}\right)$. After incubation $\left(25^{\circ} \mathrm{C}, 20 \mathrm{~min}\right)$ under shaking (150 rpm), the reaction was interrupted by the addition of $20 \mathrm{~mL}$ of acetone. The soil suspensions were centrifuged $(427 \mathrm{~g})$ for $10 \mathrm{~min}$, after which supernatant aliquots were removed for reading in a spectrophotometer at a wavelength of $490 \mathrm{~nm}$. The standard curve was obtained by adding aliquots of FDA in quantities of $0-400 \mu \mathrm{g}$ in $5.0 \mathrm{~mL}$ of phosphate buffer. The tubes were pre-hydrolyzed in boiling water for $60 \mathrm{~min}$ and transferred to flasks containing $5.0 \mathrm{~g}$ of soil and $15 \mathrm{~mL}$ of phosphate buffer. The results were expressed in $\mu \mathrm{g}$ of fluorescein per $\mathrm{g}$ of dry soil per hour.

For respiration analysis, two replicate analytical samples of $50 \mathrm{~g}$ of soil adjusted to $40 \%$ field capacity were kept in hermetically sealed plastic containers containing $10 \mathrm{~mL} \mathrm{NaOH}$ $\left(1 \mathrm{~mol} \mathrm{~L}^{-1}\right)$. After incubation $\left(25 \pm 2{ }^{\circ} \mathrm{C}\right)$ for 7 days, the absorbed $\mathrm{CO}_{2}$ was determined by titration with $\mathrm{HCl}\left(0.5 \mathrm{~mol} \mathrm{~L}^{-1}\right)$, using phenolphthalein as the indicator. The values of accumulated $\mathrm{CO}_{2}$ were expressed in $\mu \mathrm{g}$ of $\mathrm{C}$ per $\mathrm{g}$ of dry soil.

\section{Statistical analysis}

The chemical and microbiological data were evaluated for homoscedasticity by Cochran's test (Snedecor and Cochran, 1989) and the normal distribution of the residuals by the Lilliefors test. The data were then subjected to analysis of variance and the Scott-Knott test at $5 \%$ significance using the Sisvar software. Principal component analysis (PCA) was carried out using the PAST software (Hammer et al., 2004). The PCA was used to reduce the size of the dataset and to consequently facilitate analysis through evaluation of how the variables are clustered in the plot (Herlihy and McCarthy, 2006).

\section{RESULTS}

There was no effect of the treatments (100S, 100E, and 50S:50E) on soil pH (active acidity) compared with the degraded area with spontaneous vegetation (DASV) (Table 1). However, all reforestation systems increased in $\mathrm{H}+\mathrm{Al}$ (potential acidity) in both the rainy and the dry seasons compared with the DASV area (Table 1).

The planted areas (100S, 100E, and 50S:50E) were found to have higher contents of nutrients ( $\mathrm{Ca}, \mathrm{Mg}, \mathrm{P}, \mathrm{K}$, and $\mathrm{N}$ ) and carbon in the soil in relation to the DASV. In both seasons, the $100 \mathrm{~S}$ planting presented higher levels of $\mathrm{Ca}, \mathrm{P}$, and $\mathrm{K}$ in the soil compared to the other planted areas, while the levels of $\mathrm{N}$ and $\mathrm{C}$ were higher in planted areas with the presence of the legume (100S - rainy season; 50S:50E - the dry and wet seasons) (Table 1).

Both monospecific and mixed stands induced significant increases in total microbial activity in the soil when evaluated in terms of soil respiration $\left(\mathrm{CO}_{2}\right.$ production) and FDA hydrolysis (Table 2) compared to the DASV, with the exception of 100E (FDA) and 100S

Table 1. Chemical properties of soil samples from degraded area with spontaneous vegetation (DASV) and degraded area reforested with Sesbania virgata and Eucalyptus camaldulensis in monospecific (100S and 100E, respectively) and mixed (50S:50E) stands, 20 and 26 months after planting (rainy and dry seasons, respectively)

\begin{tabular}{|c|c|c|c|c|c|c|c|c|c|c|c|c|c|c|c|c|c|c|}
\hline \multirow{2}{*}{ Stand } & \multicolumn{2}{|c|}{$\mathrm{pH}\left(\mathrm{H}_{2} \mathrm{O}\right)$} & \multicolumn{2}{|c|}{$\mathrm{Al}^{3+}$} & \multicolumn{2}{|c|}{$\mathrm{H}+\mathrm{Al}$} & \multicolumn{2}{|c|}{$\mathbf{P}$} & \multicolumn{2}{|c|}{$\mathbf{K}$} & \multicolumn{2}{|c|}{$\mathrm{Ca}^{2+}$} & \multicolumn{2}{|c|}{$\mathrm{Mg}^{2+}$} & \multicolumn{2}{|c|}{$\mathbf{C}$} & \multicolumn{2}{|c|}{$\mathbf{N}$} \\
\hline & Rainy & Dry & Rainy & Dry & Rainy & Dry & Rainy & Dry & Rainy & Dry & Rainy & Dry & Rainy & Dry & Rainy & Dry & Rainy & Dry \\
\hline & & & \multicolumn{8}{|c|}{$\longrightarrow \mathrm{mmol}_{\mathrm{c}} \mathrm{dm}^{-3} \longrightarrow \mathrm{mg} \mathrm{dm}^{-3}$} & \multicolumn{4}{|c|}{$\mathrm{cmol}_{\mathrm{c}} \mathrm{dm}^{-3}$} & \multicolumn{4}{|c|}{$\mathrm{g} \mathrm{kg}^{-}$} \\
\hline $100 \mathrm{~S}$ & $6.47 \mathrm{a}$ & $6.23 a$ & $0.10 a$ & $0.07 a$ & $5.36 \mathrm{a}$ & $4.83 \mathrm{a}$ & $42.09 a$ & $34.55 a$ & 561 a & $647 a$ & $8.00 \mathrm{a}$ & $6.32 \mathrm{a}$ & $3.53 a$ & $3.14 \mathrm{a}$ & $24.90 \mathrm{a}$ & $0.40 b^{*}$ & $3.05 a$ & $2.50 b^{*}$ \\
\hline $100 \mathrm{E}$ & $6.30 \mathrm{a}$ & $5.70 \mathrm{a}$ & $0.20 \mathrm{a}$ & $0.23 \mathrm{a}$ & $4.18 \mathrm{a}$ & $4.12 \mathrm{a}$ & $14.62 \mathrm{~b}$ & $29.40 a^{*}$ & 202 b & $286 \mathrm{~b}$ & $4.55 \mathrm{~b}$ & $3.85 b$ & $3.73 \mathrm{a}$ & $2.78 \mathrm{a}$ & $16.45 c$ & $19.35 \mathrm{~b}$ & $2.10 \mathrm{C}$ & $2.35 \mathrm{~b}$ \\
\hline $50 \mathrm{~S}: 50 \mathrm{E}$ & $5.77 \mathrm{a}$ & $5.53 \mathrm{a}$ & $0.07 a$ & $0.03 a$ & $4.46 a$ & $4.61 \mathrm{a}$ & $16.05 \mathrm{~b}$ & $19.33 \mathrm{~b}$ & $145 \mathrm{~b}$ & $179 \mathrm{~b}$ & $4.34 \mathrm{~b}$ & $3.76 b$ & $3.41 \mathrm{a}$ & $3.06 \mathrm{a}$ & $20.60 \mathrm{~b}$ & $24.10 \mathrm{a*}$ & $2.60 \mathrm{~b}$ & $2.90 a^{*}$ \\
\hline DASV & $6.10 \mathrm{a}$ & $6.03 \mathrm{a}$ & $0.00 \mathrm{a}$ & $0.03 \mathrm{a}$ & $1.76 \mathrm{~b}$ & $2.14 \mathrm{~b}$ & $12.26 \mathrm{~b}$ & $14.60 \mathrm{~b}$ & $55 \mathrm{c}$ & $58 \mathrm{c}$ & $1.30 \mathrm{C}$ & $1.37 \mathrm{~b}$ & $1.79 \mathrm{~b}$ & $1.39 \mathrm{~b}$ & $5.20 \mathrm{~d}$ & $1.80 c^{*}$ & $0.30 \mathrm{~d}$ & $0.35 c$ \\
\hline
\end{tabular}

Means followed by the same letter in the same column do not differ statistically in the Scott Knott test at $5 \%$ probability. ${ }^{*}$ : difference between seasons (rainy and dry) for each treatment by Scott Knott test at $5 \%$ probability. 
(respiration) plantations in the rainy season, which showed no significant difference. Higher FDA hydrolysis rates were obtained for the $100 \mathrm{~S}$ and 50S:50E stands in the rainy season. In contrast, higher respiration values were recorded for $100 \mathrm{~S}$ in the dry season (Table 2).

Regarding seasonal variation, only influences were observed in the 100E, 100S, and 50S:50E areas. The 100E planting showed higher contents of P and FDA in the dry season, whereas the $100 \mathrm{~S}$ planting showed higher contents of $\mathrm{C}, \mathrm{N}$, and FDA in the rainy season and higher respiration in the dry season. The 50S:50E planting showed higher contents of $\mathrm{C}$ and $\mathrm{N}$ in the dry season.

The variables were distributed along two axes (PC1 and PC2), which explained $89.61 \%$ and $84.30 \%$ (rainy and dry season, respectively) of the total variation of the treatments (Figure 2). The treatments were found to have different clusters. The first group consisted of DASV, which is in the lower quadrant (Figure $2 a$ ) and the upper left quadrant (Figure 2b), that is, opposite the distribution of all the variables used in this analysis. The second

Table 2. Microbial activity of soil samples from degraded area with spontaneous vegetation (DASV) and degraded areas revegetated with Sesbania virgata and Eucalyptus camaldulensis in monospecific (100S and 100E, respectively) and mixed (50S: 50E) stands at 20 and 26 months after planting (rainy and dry seasons, respectively)

\begin{tabular}{|c|c|c|c|c|}
\hline \multirow{2}{*}{ Stand } & \multicolumn{2}{|c|}{ FDA } & \multicolumn{2}{|c|}{ Respiration } \\
\hline & Rainy & Dry & Rainy & Dry \\
\hline & \multicolumn{2}{|c|}{$\mu \mathrm{FDA} \mathrm{g}^{-1} \mathrm{~h}^{-1}$} & $\mu \mathrm{g}$ & $7^{-1}$ \\
\hline $100 \mathrm{~S}$ & 85.34 a & $63.60 a^{*}$ & $34.10 \mathrm{~b}$ & $83.05 a^{*}$ \\
\hline $100 E$ & $46.03 \mathrm{C}$ & 79.72 a* & $52.06 \mathrm{a}$ & $48.40 \mathrm{~b}$ \\
\hline 50S:50E & $65.44 \mathrm{~b}$ & 70.32 a & 41.44 a & $41.19 \mathrm{~b}$ \\
\hline DASV & $27.98 \mathrm{C}$ & $21.88 \mathrm{~b}$ & $25.52 b$ & $15.38 \mathrm{C}$ \\
\hline
\end{tabular}

FDA: Fluorescein diacetate. Means followed by the same letter in the same column do not differ statistically in the Scott Knott test at $5 \%$ probability. *: difference between seasons (rainy and dry) for each treatment by Scott Knott test at $5 \%$ probability.

(a)

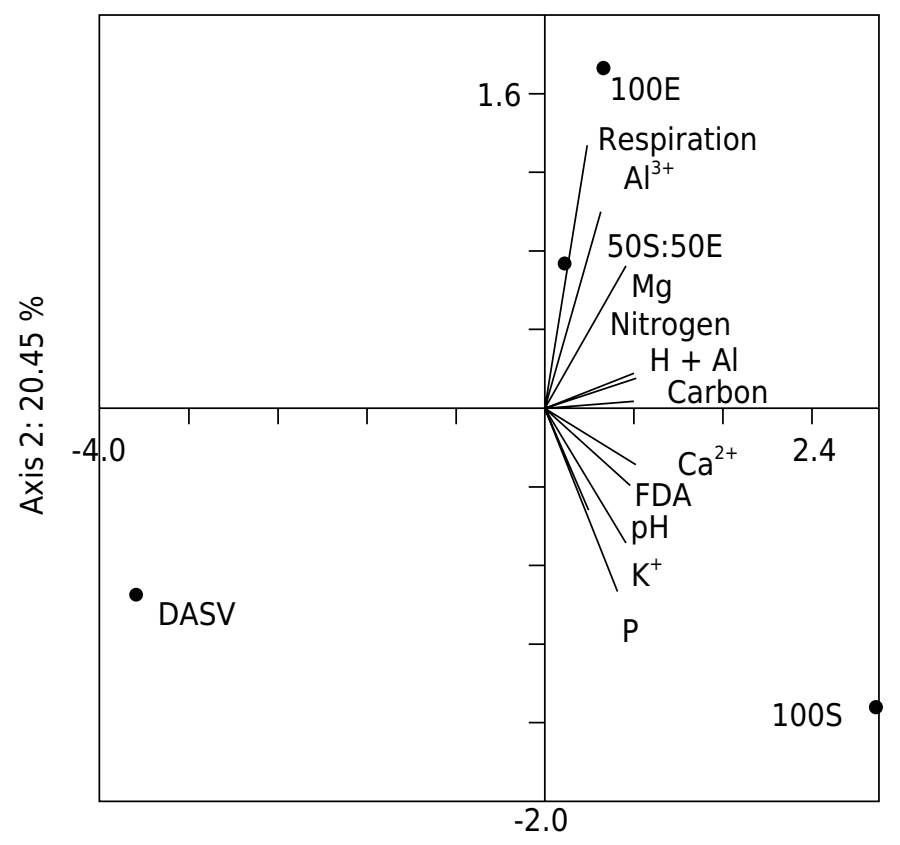

Axis 1: $68.71 \%$ (b)

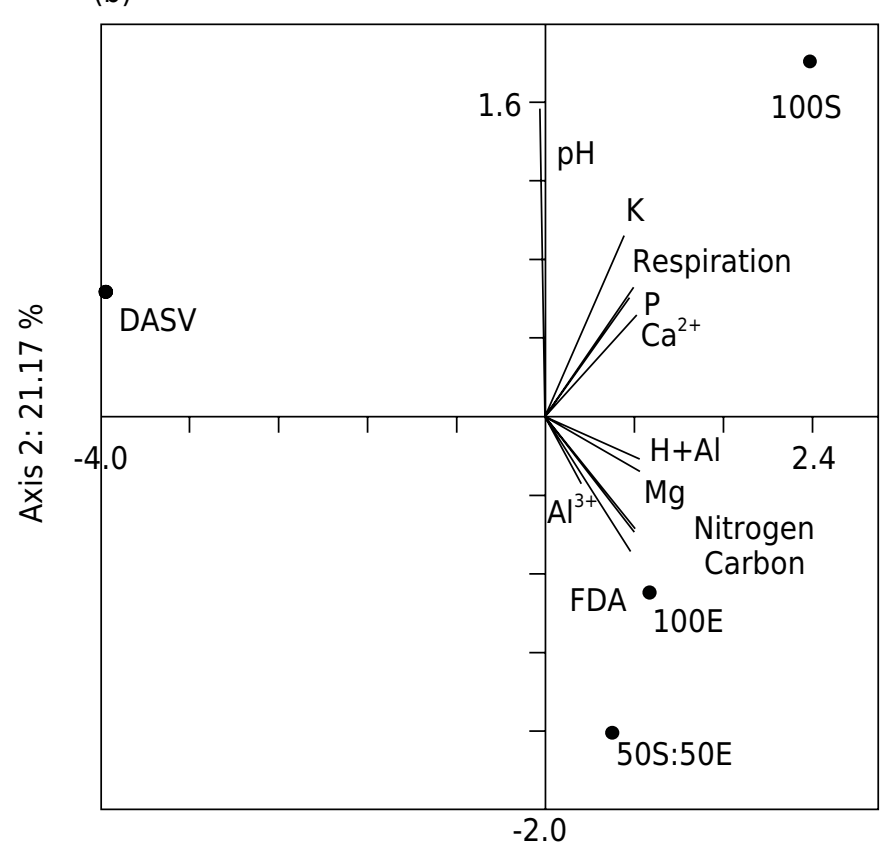

Axis 1: $68.83 \%$

Figure 2. Principal component analysis integrating chemical and microbiological characteristics of degraded area with spontaneous vegetation (DASV) and degraded areas reforested with Sesbania virgata and Eucalyptus camaldulensis in monospecific (100S and $100 \mathrm{E}$, respectively) and mixed species (50S:50E) stands in the rainy (a) and dry (b) seasons. 
group, made up of the different planting systems (100S, 100E, and 50S:50E), was located between the upper and lower right quadrants. This group was strongly correlated with the chemical and biological variables of the soil (Figures $2 a$ and $2 b$ )

\section{DISCUSSION}

Although no significant variation was observed in the active acidity $(\mathrm{pH})$ of the soil samples collected from the regenerating forest stands investigated, the potential acidity ( $\mathrm{H}+\mathrm{Al})$ was higher than the values measured for the DASV. This higher value may be due to the increase in the $\mathrm{H}^{+}$contents in the stands since the contents of $\mathrm{Al}^{3+}$, although very low, did not differ among the 100E, 100S, and 50S:50E treatments (Table 1). One of the reasons for this pattern may be the high contents of organic matter in the reforested areas compared to the DASV and the biological $\mathrm{N}_{2}$ fixation (BNF) mediated by Sesbania, a leguminous species that establishes symbioses with Rhizobia. In addition, BNF requires proton $\left(\mathrm{H}^{+}\right)$extrusion by the roots of leguminous species in order to maintain intracellular pH (Marschner and Römheld, 1983). Another hypothesis is that the rapid growth of arboreal species causes high absorption of cations to sustain growth of biomass, which promotes the high extrusion of protons $\left(\mathrm{H}^{+}\right)$to the rhizosphere to compensate for the electrochemical imbalance (Yamashita et al., 2008; Koutika et al., 2014).

While the effects of forest plantations on the chemical characteristics of the soil normally only begin to be observed several years after planting (Schiavo et al., 2009; Forrester et al., 2013), in this study, higher nutrient ( $\mathrm{Ca}, \mathrm{Mg}, \mathrm{P}, \mathrm{K}$, and $\mathrm{N}$ ) contents were observed 20 and 26 months after planting in the 100E, 100S, and 50S:50E areas than in the DASV area. Because the plantations are considered to be young and the contents of nutrients in the soil are quite high, it can be inferred that a residual effect of the soil fertilization performed during the planting of the species has occurred. However, we cannot disregard the contribution of the litter from these species to nutrient cycling. Munawar et al. (2011) evaluated litter production and decomposition in areas that had been mined and then revegetated with Albizia and Sesbania and their effects on some soil properties a year after planting. These authors observed higher contents of $\mathrm{N}$ in the two plantations in relation to the original soil (before planting), highlighting the importance of revegetation for the improvement of soil properties.

The deeper root system of the tree species may be an explanation for the improved soil fertility in the restoration area because such root systems can take in nutrients from the soil layers that are out of reach of the roots of forage plants (in this study, there was a predominance of $B$. mutica in the DASV), which are usually more shallow, and bring these nutrients to the soil surface through litter deposition (Carvalho and Xavier, 2005). Increases of 63 and $172 \%$ in Ca and Mg levels, respectively, were reported by Schiavo et al. (2009) in soils in 5-year-old Eucalyptus stands in comparison to a clay pit left to regenerate with spontaneous vegetation. In another study carried out in a clay pit, Batista (2006) observed that the P and K levels rose by 470 and $460 \%$ with the establishment of monospecific and mixed stands of a variety of Eucalyptus species and sabiá (Mimosa caesalpiniifolia Benth.) 36 months after planting.

The comparatively higher $\mathrm{Ca}, \mathrm{K}$, and $\mathrm{P}$ levels in the $100 \mathrm{~S}$ treatment in relation to the other plantations may be a consequence of the quality of the litterfall that, according to Paulucio (2007), has a lower $\mathrm{C}: \mathrm{N}$ ratio and higher contents of $\mathrm{P}$ and $\mathrm{K}$ (that is, the litterfall mostly composed of leaves) than the 50S:50E and 100E stands. In general, the release of nutrients by plant residue with a low $\mathrm{C}: \mathrm{N}$ ratio occurs more quickly than that of plants with higher $\mathrm{C}: \mathrm{N}$ values (such as Eucalyptus), since the amount of $\mathrm{N}$ affects the decomposition rate. In addition, in this same experiment, Paulucio (2007) observed that the $100 \mathrm{~S}$ planting had a leaf litter decomposition constant $(k)$ that was higher than the one in the 100E and 50S:50E plantations and therefore exhibited a lower half-life, i.e., a more rapid decomposition rate. 
The higher $\mathrm{C}$ contents observed in the plantations may have been caused by the high amounts of litterfall caused by the species in each stand compared to the area covered with spontaneous vegetation (Schiavo et al., 2007; Freitas et al., 2013). Another important factor is that the denser cover of the stands may help protect the soil more effectively against the variety of processes through which nutrients and carbon can be lost to the environment (Cunha Neto et al., 2013), such as erosion, leaching, decomposition, volatilization, and mineralization (Blum, 1997). In addition, the higher contents of $C$ in the plantations containing the $\mathrm{N}_{2}$-fixing legumes can be related to the presence of more protected or complexed organic matter, hindering the action of decomposer organisms, as suggested by Forrester et al. (2013). These authors found an increase in C in the soil with a higher proportion of $\mathrm{N}_{2}$-fixing species and observed that decomposition rates, evaluated as the percentage of acid hydrolyzable molybdenum, tended to decrease with an increase in the proportion of Acacia mearnsii.

The BNF promoted by Sesbania may explain the high $\mathrm{N}$ contents observed in the soils covered by the 50S:50E and 100S stands (Vezzani et al., 2001; Laclau et al., 2008) compared with the value observed for the monospecific Eucalyptus stands (100E). Freitas et al. (2013) detected higher N contents in the litter layer of a mixed stand composed of Eucalyptus and Acacia (a leguminous genus) than in a monospecific Eucalyptus stand. Additionally, Vezzani et al. (2001) and Forrester et al. (2004) concluded that the N contents in the soil increased in a mixed stand of Eucalyptus and another leguminous species, Acacia decurrens (the Brazilian teak), compared with the monospecific Eucalyptus stand. Higher $\mathrm{N}$ contents were found in leaf litter from the same Sesbania stands analyzed in the present study (50S:50E and 100S) than in the 100E treatment (Paulucio, 2007).

The capacity of some Eucalyptus and leguminous species to incorporate $C$ into the soil has also been reported by Garay et al. (2003), Schiavo et al. (2007), and Mendonça et al. (2008). Several studies have shed light on the possible beneficial effects of introducing extra $\mathrm{N}$ through BNF by leguminous species on the stabilization of $\mathrm{C}$ soil contents (Resende et al., 2006; Balieiro et al., 2008; Simões et al., 2010). The availability of $\mathrm{N}$ is essential to stabilization of $\mathrm{C}$ because it promotes the synthesis of more humified substances (richer in $\mathrm{N}$ ), ensuring better structural stability of the soil organic matter. In addition, the $\mathrm{N}$ of legumes (organic $\mathrm{N}$ ) is preferred in the processes of microbial synthesis of humic substances (Ribeiro et al., 2011). This may also explain the greater increase in $C$ contents in the mixed stands analyzed in the present study (50S:50E) compared to the monospecific Eucalyptus stands (100E).

The low contents of $C$ and nutrients observed in the DASV compared with the monospecific and mixed stands analyzed in the present study likely led to lower microbial activity (soil respiration and FDA). A number of studies have described the considerable importance of factors such as the composition of the plant community and the chemical properties of the soil for the maintenance of microbial populations in soils (Rachid et al., 2013; 2015). Moreover, $\mathrm{CO}_{2}$ production in the surface soil layers is directly influenced by both the amount and quality of the organic matter available (Peña et al., 2005; Souza et al., 2010).

The introduction of Eucalyptus and Sesbania likely increased the amount of litterfall accumulating on the soil, which promoted microbiological activity (Andrade et al., 2000; Simões et al., 2010), as observed in the soil respiration and FDA activity of the soil samples analyzed. According to Biederbeck et al. (1984), nutrients such as P and N play important roles in residue decay, improving the conditions for microbial growth. Rachid et al. (2013) found that mixed plantations of Eucalyptus and Acacia can ensure the integration of microorganisms adapted to decomposing the litter of each species individually, and this has positive influences on $\mathrm{P}$ and $\mathrm{N}$ contents in the soil compared to the respective monocultures.

In a study conducted by Carneiro et al. (2008), enzymatic activity expressed as FDA hydrolysis was found to increase rapidly with the reforestation of an area degraded by bauxite extraction. The authors claim that FDA activity represents the heterotrophic potential of 
soils because it represents the activity of enzyme groups that decompose organic matter (Dick et al., 1996). Other studies (Evangelista et al., 2012; Silva et al., 2012) have shown that the activity of several enzymes is influenced by the levels of organic matter in soils.

The higher contents of $\mathrm{C}$ and $\mathrm{N}$ in the soil during the rainy season compared to the dry season in the $100 \mathrm{~S}$ plantations may be associated with higher total microbial activity (FDA) in the soil at that time, which can increase litter decomposition rates and the incorporation of $\mathrm{C}$ and $\mathrm{N}$ into the soil (Batista et al., 2008; Silva et al., 2012). The same pattern may help explain the higher content of $\mathrm{P}$ during the dry season for the $100 \mathrm{E}$ planting, when there was greater FDA activity. Although there was no significant difference in FDA between the dry and rainy seasons for the 50S:50E stands, there was a tendency toward higher values of total enzyme activity in the dry season, in which the highest $\mathrm{C}$ and $\mathrm{N}$ levels were observed. Silva et al. (2012) found high correlations between the activity of different enzymes ( $\beta$-glucosidase, arylsulfatase, and acid phosphatase) and $\mathrm{C}$ in soils of forest systems at different stages of succession. The higher FDA activity in the 100E plantation and respiration in the 100S plantation in the dry season may be related to greater litter deposition rates at that time, which can stimulate microbial activity. Silva (2009) found higher litter deposition rates in the dry season in those plantations until they reached four years of age.

The analysis of the chemical and microbiological properties of the soils investigated in the present study allowed the effects of each of the clay pit reforestation approaches to be differentiated. This differentiation was clear mainly in PC1, which showed separation of the stands and DASV in both seasons. Additionally, PC1 was positively correlated with most of the variables analyzed, which were more consistently associated with the stands, suggesting positive changes in the chemical and biological properties of the soil as a result of reforestation of the clay pit, as also observed by Batista et al. (2008) and Schiavo et al. (2009). Thus, there is a negative influence of DASV based on the properties analyzed. This may be related to the lower deposition rates of plant material by this system, resulting in lower incorporation of organic matter into the soil, which may reflect the lower contents of $\mathrm{C}$ and biological activity represented by the FDA and respiration in this study (Costa et al., 2004; Cunha et al, 2012). Moreover, greater association of the microbiological variables, C, and chemical properties with the plantations (100S, 100E, and 50S:50E) may reflect the particular components of the soil in such systems; the components are not only stimulated by the continuous supply of organic materials that originate from the tree species, with different degrees of susceptibility to decay, but are also benefited by possible reduction in water erosion caused by the greater ground cover from litter (Cunha et al., 2012).

\section{CONCLUSION}

The reforestation of clay pits with Sesbania virgata and Eucalyptus camaldulensis, whether in monospecific or mixed species stands, improves the chemical and biological properties of soils and increases nutrient $(\mathrm{Ca}, \mathrm{Mg}, \mathrm{K}, \mathrm{P}$, and $\mathrm{N}$ ) and carbon contents, promoting the expansion of biological activities in soils.

\section{ACKNOWLEDGMENT}

The authors thank the Conselho Nacional de Desenvolvimento Científico e Tecnológico (CNPq) for financial support for this study.

\section{REFERENCES}

Andrade AG, Costa GS, Faria SM. Deposição e decomposição da serapilheira em povoamentos de Mimosa caesalniifolia, Acacia mangium e Acacia holosericea com quatro anos de idade em Planossolo. Rev Bras Cienc Solo. 2000;24:777-85. https://doi.org/10.1590/S0100-06832000000400010 
Arshad MA, Martin S. Identifying critical limits for soil quality indicators in agro-ecosystems. Agric Ecosyst Environ. 2002;88:153-60. https://doi.org/10.1016/S0167-8809(01)00252-3

Balieiro FC, Pereira MG, Alves BJR, Resende AS, Franco AA. Soil carbon and nitrogen in pasture soil reforested with eucalyptus and guachapele. Rev Bras Cienc Solo. 2008;32:1253-60. https://doi.org/10.1590/S0100-06832008000300033

Batista QR, Freitas MSM, Martins MA, Silva CF. Bioqualidade de área degradada pela extração de argila, revegetada com Eucalyptus spp. e sabiá. Caatinga. 2008;21:169-78.

Batista QR. Qualidade química e biológica de uma área degradada pela extração de argila, revegetada com Eucalyptus spp. e sabiá em plantios puros e consorciados [dissertação]. Campos dos Goytacazes: Universidade Estadual do Norte Fluminense Darcy Ribeiro; 2006.

Biederbeck VO, Campbell CA, Zentner RP. Effect of crop rotation and fertilization on some biological properties of a loam in southwestern Saskatchewan. Can J Soil Sci. 1984;64:355-67. https://doi.org/10.4141/cjss84-037

Blum WEH. Basic concepts: Degradation, resilience, and rehabilitation. In: Lal R, Blum WH, Valentine C, Stewart BA, editors. Methods for assessment of soil degradation. Boca Raton: CRC Press; 1997. p.1-16.

Burns RG. Soil enzymes. New York: Academic Press; 1978.

Carneiro MAC, Assis PCR, Melo LBC, Pereira HS, Paulino HB, Silveira Neto AN. Atributos bioquímicos em dois solos de cerrado sob diferentes sistemas de manejo e uso. Pesq Agropec Trop. 2008;38:276-83.

Carneiro MAC, Souza ED, Reis EF, Pereira HS, Azevedo WR. Atributos físicos, químicos e biológicos de solo de cerrado sob diferentes sistemas de uso e manejo. Rev Bras Cienc Solo. 2009;33:147-57. https://doi.org/10.1590/S0100-06832009000100016

Carter MR. Microbial biomass as an index for tillage induced changes in soil biological properties. Soil Till Res. 1986;7:29-40. https://doi.org/10.1016/0167-1987(86)90005-X

Carvalho MM, Xavier DF. Sistemas silvipastoris para recuperação e desenvolvimento de pastagens. In: Aquino AM, Assis RL, editores. Agroecologia: Princípios e técnicas para uma agricultura orgânica sustentável. Brasília, DF: Embrapa Informação Tecnológica; 2005. p. 497-517.

Carvalho AMX, Vale HMM, Ferreira EM, Cordero AFP, Barros NF, Costa MD. Atividade microbiana de solo e serapilheira em áreas povoadas com Pinus elliottii e Terminalia ivorensis. Rev Bras Cienc Solo. 2008;32:2709-16. https://doi.org/10.1590/S0100-06832008000700014

Chen W, Hoitink HAJ, Schmitthenner AF, Tuovinen $\mathrm{OH}$. The role of microbial activity in suppression of damping-off caused by Pythium ultimum. Phytophatology. 1988;78:314-22. https://doi.org/10.1094/Phyto-78-314

Claessen MEC, organizador. Manual de métodos de análise de solo. 2a ed. Rio de Janeiro: Centro Nacional de Pesquisa de Solos; 1997.

Costa FS, Bayer C, Albuquerque JA, Fontoura SMV. Aumento de matéria orgânica num Latossolo bruno em plantio direto. Cienc Rural. 2004;34:587-9. https://doi.org/10.1590/S0103-84782004000200041

Coutinho MP, Carneiro JGA, Barroso DG, Rodrigues LA, Siqueira J. Substrato de cavas de extração de argila enriquecido com subprodutos agroindustriais e urbanos para produção de mudas de sesbânia. Rev Árvore. 2006;30:147-53. https://doi.org/10.1590/S0100-67622006000100018

Cunha EQ, Stone LF, Ferreira EPB, Didonet AD, Moreira JAA. Atributos físicos, químicos e biológicos de solo sob produção orgânica impactados por sistemas de cultivo. Rev Bras Eng Agríc Amb. 2012;16:56-63. https://doi.org/10.1590/S1415-43662012000100008

Cunha Neto FV, Leles PSS, Pereira MG, Bellumath VGH, Alonso JM. Acúmulo e decomposição da serapilheira em quatro formações florestais. Cienc Flor. 2013;23:379-87. https://doi.org/10.5902/1980509810549

Dick RP, Breackwell DP, Turco RF. Soil enzyme activities and biodiversity measurements as integrative microbiological indicators. In: Doran JW, Jones AJ, editors. Methods for assessing soil quality. Madison: Soil Science Society of America; 1996. p.247-71. 
Evangelista CR, Partelli FL, Ferreira EPB, Correchel V. Atividade enzimática do solo sob sistema de produção orgânica e convencional na cultura da cana-de-açúcar em Goiás. Semina: Cienc Agrár. 2012;33:1251-62. https://doi.org/10.5433/1679-0359.2012v33n4p1251

Forrester DI, Bauhus J, Khanna PK. Growth dynamics in a mixed-species plantation of Eucalyptus globulus and Acacia mearnsii. For Ecol Manage. 2004;193:81-95. https://doi.org/10.1016/j.foreco.2004.01.024

Forrester DI, Pares A, O'Hara C, Khanna PK, Bauhus J. Soil organic carbon is increased in mixed-species plantations of eucalyptus and nitrogen-fixing acacia. Ecosystems. 2013;16:123-32. https://doi.org/10.1007/s10021-012-9600-9

Freitas ECS, Oliveira Neto SN, Fonseca DM, Santos MV, Leite HG, Machado VD. Deposição de serapilheira e de nutrientes no solo em sistema agrossilvipastoril com eucalipto e acácia. Rev Árvore. 2013;37:409-17. https://doi.org/10.1590/S0100-67622013000300004

Garay I, Kindel A, Carneiro R, Franco AA, Barros E, Abbadie L. Comparação da matéria orgânica e de outros atributos do solo entre plantações de Acacia mangium e Eucalyptus grandis. Rev Bras Cienc Solo. 2003;27:705-12. https://doi.org/10.1590/S0100-06832003000400015

Gatto A, Barros NF, Novais RF, Silva IR, Leite HG, Leite FP, Villani EMA. Estoques de carbono no solo e na biomassa em plantações de eucalipto. Rev Bras Cienc Solo. 2010;34:1069-79. https://doi.org/10.1590/S0100-06832010000400007

Gil-Sotres F, Trasar-Cepeda C, Leirós MC, Seoane S. Different approaches to evaluating soil quality using biochemical properties. Soil Biol Biochem. 2005;37:877-87. https://doi.org/10.1016/j.soilbio.2004.10.003

Green VS, Stott DE, Diack M. Assay for fluorescein diacetate hydrolytic activity: optimization for soil samples. Soil Biol Biochem. 2006;38:693-701. https://doi.org/10.1016/j.soilbio.2005.06.020

Grisi BM. Biomassa e a atividade de microrganismos do solo: revisão metodológica. Rev Nordestina Biol. 1995;10:1-22.

Guilbault GG, Kramer DN. Fluorometric determination of lipase, acylase, alpha-, and gamma-chymotrypsin and inhibitors of these enzymes. Anal Chem. 1964;36:409-12. https://doi.org/10.1021/ac60208a052

Hammer O, Harper DAT, Ryan PD. PAST - Paleontological Statistics. Version 1.12. 2004 [Accessed on: Dec 13, 2014]. Available at: http://www.folk.uio.no/ohammer/past.

Herlihy M, Mccarthy J. Association of soil-test phosphorus with phosphorus fractions and adsorption characteristics. Nutr Cycl Agroecosyst. 2006;75:79-90. https://doi.org/10.1007/s10705-006-9013-2

Klose S, Tabatabai MA. Urease activity of microbial biomass in soils as affected by cropping systems. Biol Fertil Soils. 2000;31:191-9. https://doi.org/10.1007/s003740050645

Koutika LS, Epron D, Bouillet JP, Mareschal L. Changes in N and C concentrations, soil acidity and $\mathrm{P}$ availability in tropical mixed acacia and eucalypt plantations on a nutrient-poor sandy soil. Plant Soil. 2014;379:205-16. https://doi.org/10.1007/s11104-014-2047-3

Laclau JP, Bouillet JP, Gonçalves JLM, Silva EV, Jourdan C, Cunha MCS, Moreira, MR, Saint-André L, Maquère V, Nouvellon Y, Ranger J. Mixed-species plantations of Acacia mangium and Eucalyptus grandis in Brazil: 1. Growth dynamics and aboveground net primary production. For Ecol Manage. 2008;255:3905-17. https://doi.org/10.1016/j.foreco.2007.10.050

Lal R. Restoring soil quality to mitigate soil degradation. Sustainability. 2015;7:5875-95. https://doi.org/10.3390/su7055875

Li Q, Liang JH, He YY, Hu QJ, Yu S. Effect of land use on soil enzyme activities at karst area in Nanchuan, Chongqing, Southwest China. Plant Soil Environ. 2014;60:15-20. https://doi.org/10.1007/s11631-011-0540-4

Malavolta E, Vitti GC, Oliveira SA. Avaliação do estado nutricional das plantas: princípios e aplicações. Piracicaba: Potafos; 1989.

Marschner $\mathrm{H}$, Römheld V. In vitro measurement of root-induced $\mathrm{pH}$ changes at the soil-root interface: effect of plant species and nitrogen source. Zeitschrift Pflanzenphysiol. 1983;111:241-51. https://doi.org/10.1016/S0044-328X(83)80083-X 
Mendonça AVR, Carneiro JGA, Barroso DG, Santiago AR, Freitas TAS, Souza JS. Desempenho de quatro de Eucalyptus spp em plantios puros e consorciados com sabiá (Mimosa caesalpiniaefolia Benth) em cava de extração de argila. Rev Árvore. 2008;32:395-405. https://doi.org/10.1590/S0100-67622008000300002

Munawar A, Indarmawan, Suhartoyo $\mathrm{H}$. Litter production and decomposition rate in the reclaimed mined land under albizia and sesbania stands and their effects on some soil chemical properties. J Trop Soils. 2011;16:1-6. https://doi.org/10.5400/jts.2011.16.1

Paula PD, Campello EFC, Guerra JGM, Santos GA, Resende AS. Decomposição das podas das leguminosas arbóreas Gliricidia sepium e Acacia angustissima em um sistema agroflorestal. Cienc Flor. 2015;25:791-800. https://doi.org/10.5902/1980509819696

Paulucio VO. Qualidade química e biológica de área degradada pela extração de argila, revegetada com eucalipto e leguminosas inoculados com micorrizas [tese]. Campos dos Goytacazes: Universidade Estadual do Norte Fluminense; 2007.

Pell M, Stenberg B, Torstensson L. Potential denitrification and nitrification tests for evaluation of pesticide effects in soil. Ambio. 1998;27:24-8.

Peña MLP, Marques R, Jahnel MC, Anjos A. Respiração microbiana como indicador da qualidade do solo em ecossistema florestal. Floresta. 2005;35:117-27. https://doi.org/10.5380/rf.v35i1.2435

Pereira SV, Martinez CR, Porto ER, Oliveira BRB, Maia LC. Atividade microbiana em solo do semi-árido sob cultivo de Atriplex nummularia. Pesq Agropec Bras. 2004;39:757-62. https://doi.org/10.1590/S0100-204X2004000800005

Rachid CTCC, Balieiro FC, Fonseca ES, Peixoto RS, Chaer GM, Tiedje JM, Rosado AS. Intercropped silviculture systems, a key to achieving soil fungal community management in Eucalyptus plantations. PLoS One. 2015;10:e0118515. https://doi.org/10.1371/journal.pone.0118515

Rachid CTCC, Balieiro FC, Peixoto RS, Pinheiro YAS, Piccolo MC, Chaer MG, Rosado AS. Mixed plantations can promote microbial integration and soil nitrate increases with changes in the $\mathrm{N}$ cycling genes. Soil Biol Biochem. 2013;66:146-53. https://doi.org/10.1016/j.soilbio.2013.07.005

Ramos IS, Alves MG, Alexandre J. Diagnóstico do polo cerâmico de Campos dos Goytacazes - RJ. Ceram Ind. 2006;11:28-32.

Resende AS, Macedo MO, Campello EFC, Franco AA. Recuperação de áreas degradadas através da reengenharia ecológica. In: Garay I, Becker BK, organizadores. Dimensões humanas da biodiversidade: o desafio de novas relações sociedade-natureza no século XXI. Petrópolis: Editora Vozes; 2006. p.315-40.

Ribeiro PH, Santos JVVM, Coser SM, Nogueira NO, Martins CAS. Adubação verde, os estoques de carbono e nitrogênio e a qualidade da matéria orgânica do solo. Rev Verde. 2011;6:43-50. https://doi.org/10.18378/rvads.v6i1.476

Rodrigues LA, Martins MA, Salomão MSMB. Uso de micorrizas e rizóbio com cultivo consorciado de eucalipto e sesbânia: I - Crescimento, absorção e transferência de nitrogênio entre plantas. Rev Bras Cienc Solo. 2003;27:583-91. https://doi.org/10.1590/S0100-06832003000400002

Rodrigues LA, Barroso DG, Martins MA, Mendonça AVR. Revegetação de áreas degradadas pela extração de argila no Norte do Estado do Rio de Janeiro. Perspectivas. 2006;5:88-105.

Roscoe R, Boadey RM, Salton JC. Sistema de manejo e matéria orgânica do solo. In: Roscoe $\mathrm{R}$, Mercante FM, Salton JC, editores. Dinâmica da matéria orgânica do solo em sistemas conservacionistas: modelagem matemática e métodos auxiliares. Dourados: Embrapa Agropecuária Oeste; 2006. p.17-42.

Rotman B, Papermaster BW. Membrane properties of living mammalian cells as studied by enzymatic hydrolysis of fluorogenic esters. Proc Nat Acad Sci. 1966;55:134-41. https://doi.org/10.1073/pnas.55.1.134

Samôr OJM. Comportamento de mudas de Sesbania virgata e Anadenanthera macrocarpa, produzidas em diferentes recipientes e substratos, destinadas à recuperação de áreas degradadas pela extração de argila [dissertação]. Campos dos Goytacazes: Universidade Estadual do Norte Fluminense; 1999. 
Santiago AR, Barroso DG, Mendonça AVR, Freitas TAS, Lamônica KR, Carneiro JGA. Influência do sistema de plantio sobre atributos químicos de substrato de cava de extração de argila. Floresta. 2009;39:597-604. https://doi.org/10.5380/rf.v39i3.15359

Santos JV, Rangel WM, Guimarães AA, Jaramillo PMD, Rufini M, Marra LM, López MV, Silva MAP, Soares CRFS, Moreira FMS. Soil biological attributes in arsenic-contaminated gold mining sites after revegetation. Ecotoxicology. 2013;22:1526-37. https://doi.org/10.1007/s10646-013-1139-9

Schiavo JA, Busato JG, Martins MA, Canellas LP. Recovery of degraded areas revegeted with Acacia mangium and Eucalyptus with special reference to organic matter humification. Sci Agric. 2009;66:353-60. https://doi.org/10.1590/S0103-90162009000300010

Schiavo JA, Canellas LP, Martins MA. Revegetação de cava de extração de argila com Acacia mangium. I - Atributos químicos do solo, ácidos fúlvicos e húmicos. Rev Bras Cienc Solo. 2007;31:1153-62. https://doi.org/10.1590/S0100-06832007000500030

Schiavo JA, Martins MA, Rodrigues LAR. Crescimento de mudas de Acacia mangium, Sesbania virgata e Eucalytpus camaldulensis, inoculadas com fungos micorrízicos, em casa-de-vegetação e em cava-de-extração de argila. Acta Sci Agron. 2010;32:171-8. https://doi.org/10.4025/actasciagron.v32i1.7309

Schiavo JA. Revegetação de áreas degradadas pela extração de argila, com espécies micorrizadas de Acacia mangium, Sesbania virgata e Eucalyptus camaldulensis [tese]. Campos dos Goytacazes: Universidade Estadual do Norte Fluminense Darcy Ribeiro; 2005.

Schloter M, Dilly O, Munch JC. Indicators for evaluating soil quality. Agric Ecosyst Environ. 2003;98:255-62. https://doi.org/10.1016/S0167-8809(03)00085-9

Schulz S, Brankatschk R, Dumig A, Kögel-Knabner I, Schloter M, Zeyer J. The role of microorganisms at different stages of ecosystem development for soil formation. Biogeosciences. 2013;10:3983-96. https://doi.org/10.5194/bg-10-3983-2013

Silva CF. Atributos químicos e biológicos em cavas de extração de argila revegetadas com eucalipto e leguminosas [Tese]. Campos dos Goytacazes: Universidade Estadual do Norte Fluminense Darcy Ribeiro; 2009.

Silva CF, Martins MA, Silva EMR, Pereira MG, Correia MEF. Influência do sistema de plantio sobre atributos dendrométricos e fauna edáfica, em área degradada pela extração de argila. Rev Bras Cienc Solo. 2013;37:1742-51. https://doi.org/10.1590/S0100-06832013000600030

Silva CF, Pereira MG, Miguel DL, Feitosa JCF, Loss A, Menezes CEG, Silva EMR. Carbono orgânico total, biomassa microbiana e atividade enzimática do solo de áreas agrícolas, florestais e pastagem no médio Vale do Paraíba do Sul (RJ). Rev Bras Cienc Solo. 2012;36:1680-9. https://doi.org/10.1590/S0100-06832012000600002

Silva M, Siqueira ER, Costa JLS. Hidrólise de diacetato de fluoresceína como bioindicador da atividade microbiológica de um solo submetido a reflorestamento. Cienc Rural. 2004;34:1493-6. https://doi.org/10.1590/S0103-84782004000500025

Simões SMO, Zilli JE, Costa MCG, Tonini H, Balieiro FC. Carbono orgânico e biomassa microbiana do solo em plantios de Acacia mangium no Cerrado de Roraima. Acta Amaz. 2010;40:23-30. https://doi.org/10.1590/S0044-59672010000100003

Snedecor GW, Cochran WG. Statistical methods. 8th ed. Ames: lowa State University Press; 1989.

Souza ED, Costa SEVGA, Anghinoni I, Lima CVS, Carvalho PCF, Martins AP. Biomassa microbiana do solo em sistema de integração lavoura-pecuária em plantio direto, submetido a intensidades de pastejo. Rev Bras Cienc Solo. 2010;34:79-80. https://doi.org/10.1590/S0100-06832010000100008

Stenström J, Stenberg B, Johansson M. Kinetics of substrate-induced respiration (SIR): theory. Ambio. 1998;27:35-9.

Taylor JP, Wilson B, Mills MS, Burns RG. Comparison of microbial numbers and enzymatic activities in surface soils and subsoils using various techniques. Soil Biol Biochem. 2002;34:387-401. https://doi.org/10.1016/S0038-0717(01)00199-7

Valicheski RR, Marciano CR, Pociano NJ. Avaliação econômica da reutilização de áreas degradadas pela extração de argila em Campos dos Goytacazes - RJ. Rev Ceres. 2009;56:1-8. 
Vezzani FM, Tedesco MJ, Barros NF. Alterações dos nutrientes no solo e nas plantas em consórcio de eucalipto e acácia negra. Rev Bras Cienc Solo. 2001;25:225-31. https://doi.org/10.1590/S0100-06832001000100024

Viera M, Schumacher MV, Araújo EF, Corrêa RS, Caldeira MVW. Deposição de serapilheira e nutrientes em plantio de Eucalyptus urophylla X E. globulus. Flor Amb. 2014;21:327-38. https://doi.org/10.1590/2179-8087.053913

Voigtlaender M, Laclau JP, Gonçalves JLM, Piccolo MC, Moreira MZ, Nouvellon Y, Ranger J, Bouillet JP. Introducing Acacia mangium trees in Eucalyptus grandis plantations: consequences for soil organic matter stocks and nitrogen mineralization. Plant Soil. 2012;352:99-111. https://doi.org/10.1007/s11104-011-0982-9

Yamashita N, Ohta S, Hardjono A. Soil changes induced by Acacia mangium plantation establishment: comparison with secondary forest and Imperata cylindrica grassland soils in South Sumatra, Indonesia. For Ecol Manage. 2008;254:362-70. https://doi.org/10.1016/j.foreco.2007.08.012 